\title{
DA POLÔNIA AO BRASIL, COM BAGAGEM CULTURAL E LINGUÍSTICA. O QUE UMA PESSOA LEVA DENTRO DE SI?
}

\author{
From Poland to Brazil with Cultural and Linguistic Baggage. What Does \\ One Carry Inside?
}

\author{
Jolanta TAMBOR \\ Uniwersytet Śląski \\ Universidade da Silésia, Polônia \\ jolanta.tambor@us.edu.pl \\ https://orcid.org/0000-0002-0801-3821
}

RESUMO: O presente texto, escrito por ocasião dos dez anos de existência do único Curso de Letras Polonês na América do Sul, na UFPR, registra a fascinação pelos rumos tomados pelos descendentes de poloneses no Brasil e o encantamento pelo excelente estado do idioma polonês da geração mais antiga e da geração intermediária. As descrições apresentadas são estudos de casos. Não deixa de ser surpreendente a permanência do sistema da língua polonesa no Brasil por tanto tempo em condições muito desfavoráveis. O grau de polonidade e de brasilidade na identidade de cada descendente é discutido levando em conta diferentes fatores: tempo de permanência no Brasil, em que geração de descendentes o indivíduo se insere, papel desempenhado na vida, sendo também influenciado pela percepção dos conceitos de pátria e língua nativa. Nesse ponto, torna-se inevitável uma discussão sobre os conceitos língua materna/língua nativa sob a ótica da cultura polonesa. O início do século XXI é visto como um novo ponto de virada no que concerne à identidade polonesa no Brasil, em que essa identidade passa por um renascimento; por outro lado, esse momento marca também o frequente desvio da geração mais jovem da aquisição da língua polonesa nos lares. A língua polonesa na comunidade polonesa, é uma língua-vínculo para as gerações mais antigas; para os jovens pode se tornar uma língua de contato com o mundo e com a grande comunidade de descendentes de poloneses no Brasil e em vários outros países. PALAVRAS-CHAVE: Migração; Identidade; Comunidade polonesa no Brasil; Língua materna.

ABSTRACT: The present text, written for the occasion of ten years of existence of the Faculty of Polish Studies in South America, at UFPR, contains stories of Brazilian Poles and talks about my admiration for the excellente Polish language maintenance by the older and middle-aged generations. The descriptions are case studies. The 
Polish language spoken by Poles in Brazil shows how excellently the system of the language has been maintained for many generations in unfavourable conditions. The degree to which Polish and Brazilian identities are perceived in the composition of the identity of a concrete person depends on many factors: the length of their stay in Brazil, the generation of immigrants they belong to, and their life role. It is also influenced by the way the terms "homeland" and "mother tongue" are understood. The concepts of ethnic and cultural identity and mother tongue are difficult to define, especially in borderland or migration situations, and it is also important to be aware of the significance of expressions equivalent to "mother tongue"/"native language" in Polish culture. The start of the 21 st century marks a new turning point in the studies of Polish identity in Brazil, in which this identification is experiencing a renaissance; on the other hand, in this moment members of the youngest generation often do not use their ancestors' language in their family home. For the Polish community in Brazil, Polish is a language of bonding for the older generations, while for the youngest ones it may become a language used for contact with the world at large and with the big Polish diaspora living in Brazil and in other countries. KEYWORDS: Migration; Identity; Polish community in Brazil; Mother tongue.

STRESZCZENIE: Tekst został napisany z okazji 10-lecia powstania jedynej polonistyki w Ameryce Płd, na UFPR. Zawiera zapis fascynacji losami Polaków brazylijskich i oczarowania wspaniałym stanem polszczyzny ich starszego i średniego pokolenia. Wszelkie ustalenia i opisy to studia przypadków. W zjawisku polszczyzny brazylijskiej zadziwia utrzymanie systemu polszczyzny przez tak długi czas (kilka pokoleń) w bardzo niesprzyjających warunkach. W artykule wskazuję, że stopień polskości i brazylijskości w tożsamości każdej z osób polskiego pochodzenia w Brazylii zależy od wielu czynników - długości pobytu w Brazylii, pokolenia imigranckiego, roli życiowej itp. Zależy też od rozumienia pojęć ojczyzny i języka ojczystego. Pokazuję, że tożsamość etniczna i kulturowa, język ojczysty bywa trudna do ustalenia szczególnie w sytuacjach pogranicza czy sytuacji emigracji, a szczególnie kolejnych pokoleń na emigracji. Uważam, że początek XXI w. wyznacza nową cezurę w badaniach polskiej tożsamości w Brazylii. Polska identyfikacja migrantów przeżywa renesans. Widoczny jest nawrót do postrzegania języka jako podstawowego komponentu tożsamości. Początek XXI wieku zrodził też, niestety, nowe zjawisko - najmłodsze pokolenie, często całkowicie odchodzi od języka jako fenomenu wynoszonego $\mathrm{z}$ domu. Dla Polonii język polski jest- w starszych pokoleniach językiem więzi, w najmłodszych może stać się językiem kontaktu ze 
światem i z wielką społecznością Polonii brazylijskiej i światowej. SŁOWA KLUCZOWE: Migracja; Tożsamość; Polonia brazylijska; Język ojczysty.

\section{COMO CHEGAMOS AQUI?}

A celebração do jubileu do curso de Letras- Polonês em Curitiba, $10^{\circ}$ aniversário do primeiro e, até o momento, único curso do gênero na América do Sul, foi o fato que me motivou a abordar a questão apresentada no título do presente artigo.

No começo do meu fascínio pelo Brasil encontra-se a proposta de cooperação da Universidade de Silêsia com o Curso de Letras Polonês da Universidade Federal do Paraná feita por Aleksandra Piasecka-Till. Um ano após essa reunião, nosso Reitor, como Presidente da KRASP (Conferência dos Reitores das Instituições Acadêmicas Polonesas), voaria para o Brasil para participar na conferência intitulada Innovative Strategies for Higher Education in Latin America and Europe: International Collaboration and Regional Development, que se realizou em São Paulo, de 11 a 14 de novembro de 2012, como parte do programa Alfa Puentes, ou seja, um projeto de cooperação internacional entre a Europa e América Latina, com o objetivo de melhorar e modernizar o sistema de ensino superior latinoamericano e harmonizar os currículos entre os dois continentes. O Professor W. Banyś concordou em incluir Curitiba em seu plano de viagem para se reunir com o Vice-Reitor da Universidade Federal do Paraná (UFPR), Prof. Rogério Andrade Mulinari e com o Cônsul-Geral da República da Polônia em Curitiba, Sr. Marek Makowski, com vistas à assinatura de um acordo bilateral entre a Universidade da Silésia e a Universidade Federal do Paraná.

No ano seguinte após a assinatura do contrato, durante o verão polonês decidimos iniciar a cooperação através de uma série de palestras. Estive aí com meu marido, Prof. Romuald Cudak, que deu palestras sobre literatura e eu dei palestras sobre língua. Alojamo-nos na casa de nossos amigos brasileiros, Rita e Sidney. Além de palestras e seminários, participamos de duas conferências: uma relacionada à Alta Silésia (uma das regiões polonesas, que tem como capital Katowice) - que eu tive a honra de abrir, a outra sobre Skamander, mas acima de tudo sobre Julian Tuwim, que foi aberta pelo Prof. Cudak. Provavelmente esta seja a parte mais importante de meu relato: em duas ocasiões, conhecemos pessoas de origem polonesa, que participavam de aulas de língua polonesa no CELIN - Centro de Línguas e Interculturalidade - um programa da UFPR que tenta responder às necessidades tanto de pessoas da comunidade universitária como externas a ela, promovendo cursos de línguas para grupos étnicos do Paraná, incluindo, claro, cursos 
de língua polonesa. Lá conhecemos pessoas maravilhosas, descendentes de imigrantes do século XIX no Brasil. Entre eles estava Mafalda, que nos convidou para sua casa e para as casas de suas amigas na Colônia Dom Pedro II. O Sr. Michał me ofereceu fotocópias de documentos de família, de seus bisavós que tinham viajado da Polônia para o Brasil. Na Colônia Dom Pedro II, comecei a gravar meus interlocutores, porque suas histórias eram extremamente fascinantes. Por isso, pensei que tudo, que fosse possível, deveria ser feito para não esquecer essas histórias. E então eu conheci Marcia Kovalczyk, que concordou em nos levar para a casa da família dela e dos amigos em Cruz Machado e Santana.

Fiquei fascinada pelos destinos que haviam tomado meus interlocutores e seus ancestrais, mas o que mais me encantou foi a qualidade do polonês usado pela geração mais antiga e pela geração intermediária de pessoas com raízes polonesas que vivem no Brasil. Afinal, é a quarta e talvez a quinta geração de imigrantes. Não especificarei aqui o termo "geração", pois uso-o no sentindo não terminológico, ou seja, bisavós - avós pais - filhos - netos.

\section{IDENTIDADE DA COMUNIDADE POLONESA NO BRASIL}

O fenômeno da língua polonesa no Brasil é extremamente interessante para nós. Por um lado, não deixa de ser supreendente que o sistema da língua polonesa tenha se mantido por tanto tempo (várias gerações) em condições políticas muito desfavoráveis (proibições de uso de língua étnicas); por outro lado, existem fatos linguísticos interessantes que basicamente se repetem nas enunciações de várias pessoas - os lexemas transferidos para a língua polonesa do português com as características terminações polonesas, pronúncia à maneira polonesa, etc.

Władysław Miodunka, autor do estudo Bilingwizm polsko-portugalski w Brazylii (O bilinguismo polono-português no Brasil, 2003), marcou o ponto de virada de 1970 como um elemento importante nas mudanças de identidade dos descendentes de poloneses no Brasil:

Em 1970, a identidade da comunidade polonesa no Brasil mudou simbolicamente. Dos poloneses no Brasil, passando pela comunidade polaca, coletividade polonesa, depois polono-brasileira, polonesabrasileira, eles se tornaram a comunidade brasileiro-polonesa. Tornaram-se brasileiros de origem polonesa. [...] Os termos portugueses aqui apresentados se referem às diferentes etapas da identidade polonesa no Brasil. A primeira etapa é o polonês no Brasil, ou seja, polonês temporariamente estabelecido no Brasil. Se ele se sente muito 
conectado ao Brasil, pode se considerar um polonês brasileiro. A próxima etapa é a identidade dividida: meio polonesa, meio brasileira. Evoluindo mais, a identidade vai para ser brasileiro através da etapa de ser brasileiro de ascendência polonesa. Então, como se pode ver, a identidade é considerada um certo tipo de continuum entre dois pontos extremos: o polonês e o brasileiro. Passando de um ponto extremo a outro, a identidade contém cada vez menos elementos poloneses e cada vez mais brasileiros. O ponto médio é uma identidade dividida, ou seja, meio polonesa, meio brasileira (MIODUNKA, 2003, p. 56-57).

Felizmente para nós, poloneses, porque nós, sendo uma nação cultural, vemos na língua, nas tradições e no amor pela história, um dos componentes mais importantes da identidade nacional, esse estágio intermediário, a etapa da identificação dividida, continua nas gerações subseqüentes. Não podemos determinar em termos percentuais o grau de polonidade e brasilidade na identidade de cada pessoa de origem polonesa no Brasil. Tudo depende de muitos fatores - não apenas do tempo de permanência no Brasil, não apenas do número da geração de imigrantes que alguém representa, mas também do momento da vida, do papel que uma determinada pessoa desempenha na vida, do interlocutor e da pergunta que ele faz. Às vezes, é apenas durante a conversa, ao tentar responder a uma pergunta mais direta, que surge um novo pensamento, uma ideia que nunca foi concebida antes. Passando pelos estágios subsequentes marcados no texto de Miodunka, a transição para a etapa seguinte não é uma função linear, é cheia de laços e nós, caracterizada por emaranhados e retornos. Parece-me que para as nações como a polonesa, ou seja, nações culturais, essa curva emaranhada é mais difícil do que para outras nações políticas, estatais. Entre os fatores básicos que definiem ambos os tipos de nação (ALTERMATT, 1998; CHLEBOWCZYK, 1977, 1983; KŁOSKOWSKA, 1996) o mais frequentemente indicado é o fato de que, no caso de nações políticas, o uso da língua é pouco determinante, enquanto as nações culturais baseam-se na língua e cultura. Nessas últimas, a língua é um dos determinantes nacionais mais importantes.

Essa diferença também causa uma percepção um pouco diferente dos conceitos de pátria e língua nativa ${ }^{1}$. O termo língua nativa não significa a mesma coisa em todas as línguas nem em todas as comunidades nacionais. Para nós, poloneses, a língua nativa é um termo fortemente carregado de ideologia. É por isso que não podemos realmente comparar as definições da língua nativa (materna, "da mãe") com as definições, por

\footnotetext{
${ }^{1}$ Nota da redação: O termo "língua nativa" será usado quando no original a autora usa "język ojczysty".
} 
exemplo, estadunidenses. Esse termo não pode ser objetivado. A ideologização na língua polonesa significa que se trata de język ojczysty, "língua pátria", "língua da pátria", não materna, porque tem uma relação clara com nossa pátria (ojczyzna), não com nosso pai ou mãe. Embora usemos também a expressão język macierzysty, com o significado de "língua nativa", ou, mais propriamente, "língua matriz", a terra natal ainda é o ponto de referência ${ }^{2}$ - observe-se que não usamos język macierzyński, que seria "língua materna", "língua da mãe". Portanto, não podemos tentar identificar totalmente nosso nome com alguns da Europa Ocidental: Muttersprache, mother tongue, langue maternelle, nos quais o significado de 'mãe' é, no entanto, claro. Nas definições ocidentais, podem se encontrar componentes (língua da mãe; língua que a mãe transmitiu aos descendentes; do lado materno) que estão ausentes na acepção polonesa do nome. Portanto, se quisermos usar um equivalente para o język ojczysty (língua nativa), teremos que usar o adjetivo macierzysty (“da matriz"), e não macierzyński ("materno", “da mãe”), ou seja, que está relacionado a macierz (matriz = pátria, de origem, principal), e não a mać = mãe.

Mas o estabelecimento do nome - embora muito importante, porque mostra uma menor determinação por fatores biológicos, focando na escolha individual e na mensagem social - em última análise, não é a coisa mais importante. A questão incomparavelmente mais importante é: o que é a língua nativa? De que língua se trata? Qual é a relação emocional do usuário em relação a uma língua específica - uma das duas ou a que mais usam.

Geralmente, a língua nativa é identificada com a que também é às vezes chamada de primeira (ver também MIODUNKA, 2003, p. 170 e segs.), ou seja, a que foi dominada mais cedo (adquirida, assimilada, e não aprendida). Tal significado poderia ser adotado para simplificar - se estivéssemos realmente falando sobre a língua "da mãe" ou "do pai”. No entanto, no caso da Polônia e dos poloneses - uma nação cultural determinada pela língua, não é assim que entendamos o termo język ojczysty (língua nativa). O senso de identidade e identificação nacional polonês é determinado por fatores culturais, entre os quais a língua desempenha um papel importante. A identificação nacional não é, ou não

\footnotetext{
${ }^{2}$ No polonês moderno, a palavra mać $<*$ mat ' (matriz) perdeu seu significado original 'mãe' (permaneceu apenas em uma maldição e como um morfema vinculado nas palavras: útero, porca, etc.). A palavra matriz (macierz que vem de mać) realmente existe apenas em relação a 1) pátria, 2) termo matemático. O adjetivo macierzyński é usado apenas em relação ao significado antigo: macierz (matriz) = 'mãe' (licença de maternidade - urlop macierzyński, amor materno - miłość macierzyńska), enquanto macierzysty é usado em relação ao significado básico atual: macierz = 〈pátria〉 (macierzysty język (língua pátria) ou metaforicamente relacionado à pertença de alguém: macierzysty zaktad, macierzysty port (estabelecimento principal, porto de origem).
} 
precisa ser, a mesma que a pertença nacional. Há também situações específicas em que o senso de identificação nacional não é óbvio, é uma questão de escolha. Isso pode incluir:

- situação nas zonas fronteiriças - por exemplo, Silésia (influências polonesas, alemãs, tchecas e sentimento étnico silesiano), muitos silesianos (inclusive eu) pronunciaram as primeiras palavras e frases em silesiano antes que eles adquirissem a capacidade de usar o polonês geral;

- a situação da emigração e, especialmente, das gerações subseqüentes no outro território: por exemplo, uma candidata (cujos avós eram poloneses deportados em 1936) para estudante (na Polônia) afirma no Cazaquistão que quer estudar na Polônia, porque são suas terras nativas, pois são de lá os avós dela, têm suas raízes lá, e ela acrescenta: "depois da formatura, quero voltar aqui porque fui educada aqui, cresci aqui, aqui estão meus amigos e pais, aqui é minha pátria" (é possível ter duas pátrias?); no Canadá, Estados Unidos, Grã-Bretanha, Brasil - há crianças de origem polonesa nascidas lá, mas elas realmente consideram a Polônia como sua pátria? Na verdade cresceram culturalmente nesses países, frequentam high-school, pegam cursos em um college ou em uma universidade, viajam usando highway e subway, se separam de outros grupos, comem laranże e cultivam milijo ${ }^{3}$. Não entendem os jogos de palavras ou alusões presentes nos anúncios, os quais se baseam nos textos literários poloneses, literatura infantil e juvenil polonesas.

O polonês pode ser uma língua nativa para essas pessoas? Pode, mas não necessariamente. E certamente não precisa ser a primeira língua ou língua primária.

W. Miodunka (1980) ressalta que a língua nativa organiza a visão e a interpretação do mundo (językowy obraz świata) e que somente essa língua parece lógica, natural e fácil. Mas nossas descobertas nos levam a concluir que realmente se trata dessa língua básica, porque atribuir a uma língua o termo "materna" ou "nativa" geralmente é uma questão de escolha e relacionamento emocional. Não podemos concordar totalmente com as afirmações de que a língua nativa é a língua "realmente" expressiva, aquela em que sentimos, aquela em que vivemos nossas experiências. Se uma pessoa pode escolher sua terra natal e sua língua nativa/materna, às vezes é mais fácil sentir em sua língua principal. A língua nativa pode ser muito menos internalizada. Às vezes, atingir a definição completa da identificação nacional (ou étnica) e, portanto, escolher a língua envolvida na construção da identidade é um processo de longa duração. Os alunos muitas vezes

\footnotetext{
${ }^{3}$ Nota da redação: palavras "larenże" e "milijo" referem-se aqui a empréstimos lexicais presentes na língua polonesa no Brasil que veem, respectivamente, das palavras "laranjas" e "milho".
} 
passam por um período de rebeldia contra a identidade dos pais e a rejeitam. Predomina o desejo de se tornar/ser igual aos outros ao redor, o que está associado a uma relutância em usar a língua que não é observada entre os coetâneos. No entanto, a língua dos pais é frequentemente uma língua em potencial.

Nas conversas que gravei ${ }^{4}$, para a pergunta "como é mais fácil pensar e conversar hoje?" vinha a resposta que era mais fácil pensar em brasileiro/português, porque a vida continuava em português, porque no trabalho, na escola, na loja e no escritório e na rua se falava português. Portanto, é mais fácil pensar e falar palavras em português. Mas a maneira de construção de frases com essas palavras pode ser, às vezes a polonesa, o que é resultado da educação em uma casa polonesa, das tradições polonesas ou de uma imagem da Polônia e polonidade sacralizada e idealizada.

\section{A LÍNGUA POLONESA NO INÍCIO DO SÉCULO XXI}

No entanto, parece que hoje é chegada a hora de definir mais um ponto de virada. Trata-se do começo do século XXI. Os grupos estudados por W. Miodunka incluem pessoas para quem a língua era um elemento importante da identidade étnica (étnicanacional). Obviamente, era uma língua preservada em vários níveis, dependendo da situação de cada pessoa em particular. As maneiras de preservar a língua polonesa foram diferentes no caso das pessoas oriundas de famílias monoétnicas, daquelas cujos pais formavam casamentos mistos, daquelas que obtiveram educação, daquelas que viviam no meio polonês, em sua colônia, permanecendo quase a vida toda sem estudar na cidade. A nacionalidade do cônjuge em um casamento misto não deixou de ter significado. Como escreve Miodunka (2003, p. 51), "poloneses eram vistos como um grupo étnico socialmente deficiente", o que foi influenciado pelo baixo nível de educação de muitos imigrantes e pela natureza camponesa dessa imigração. Em casamentos com pessoas de origem italiana ou portuguesa, por exemplo, esta segunda cultura ocupava um lugar de predominância:

Ludzie tutej sie wstydały powiedzieć, że sóm Polacy. Były takie, co sie wstydały, boWłochy sie pośmiywały. Tołónniepowiedzioł, zejes Polak.

(As pessoas aqui tinham vergonha de dizer que eram poloneses.

\footnotetext{
${ }^{4}$ Nos anos 2014-2017 realizei pesquisas na Colônia Dom Pedro II e em Cruz Machado. Todas as citações, caso indicado diferentemente, fazem parte das minhas gravações. Essas pesquisas foram descritas também em TAMBOR, 2018, p. 221-236.
} 
Havia pessoas que tinham vergonha porque os italianos riam. Então ele não disse que era polonês) $)^{5}$.

A vergonha e a sensação de "inferioridade" deixam sua marca até hoje. Por essa razão, existem indivíduos de gerações anteriores que não falam polonês, lembram-se de certas frases desde a infância, sem saber em muitos casos o que significam. Conheci algumas dessas pessoas, que de repente extraíam dos recantos da memória algumas palavras, que ouviram na infância na casa de suas avós. Mas elas não são o centro do meu discurso, são apenas o pano de fundo. Minha atenção é atraída pelos descendentes de migrantes poloneses que mantiveram a língua trazida por seus bisavós através do oceano.

O início do século XXI mudou a situação das pessoas com raízes polonesas (aliás, não apenas polonesas e não apenas no Brasil). Mesmo aqueles cuja origem tem sido apenas uma vaga memória familiar, começaram a anunciar em alto e bom tom sua origem polonesa (o reitor da PUCPR - a Pontifícia Universidade Católica do Paraná, em Curitiba -, falou sobre isso, por exemplo, em 2016 na abertura das oficinas organizadas pela Universidade da Silésia na PUC-PR) e, em parte, se deram o trabalho de aprender a língua polonesa e visitar o país dos antepassados. É um grande esforço, porque, como diz um dos interlocutores: "to jest daleko i drogo, bo gdyby tylko przelot, to by było taniej, ale to trzeba wszysko płacić" ("é muito caro e muito longe, porque se fosse apenas um voo, seria mais barato, mas é preciso pagar tudo").

Certamente, vários projetos de educação e autoeducação nem sempre foram bemsucedidos. Não se conseguiu pôr em funcionamento o leitorado da língua polonesa na PUC-PR (ao lado do bem-sucedido Curso de Letras-Polonês que está em funcionamento na UFPR há dez anos), mas o interesse em aprender polonês nessa universidade, vários ciclos de aulas para iniciantes, uma publicação sobre estudos poloneses na revista Universidade em Debate da PUC-PR (TAMBOR; CUDAK; ACHTELIK, 2014, p. 52-59), são elementos importantes para reavivar o interesse pelo polonês em vários ambientes, não somente dentro da comunidade polonesa no Brasil. Outro exemplo de reavivamento étnico é o interesse incomum entre os representantes de várias gerações - desde as mais antigas até o momento (idade: 70-80 anos) até estudantes - nas escolas de verão na Polônia. Elas são atendidas por pessoas que falam bem o polonês e aquelas que começaram a aprender polonês na universidade em um sistema de estudo regular ou como parte de cursos organizados pela UFPR e não só, porque nos últimos anos, temos observado um reavivamento incrível, também na cidade de Irati, PR. Vale a pena ressaltar

\footnotetext{
${ }^{5}$ Todos os grifos nas falas citadas são da autora do artigo.
} 
que esses poloneses brasileiros vêm à Polônia precisamente para participar nos cursos de língua, ficando mais tempo após o fim dos cursos de verão para vistar o país e mostrá-lo aos cônjuges de outra nacionalidade. Há uma tendência visível de perceber a língua como um componente básico da identidade.

\section{A GERAÇÃO MAIS JOVEM NO SÉCULO XXI}

Infelizmente, o início do século XXI também deu origem a um novo fenômeno, oposto ao descrito - a geração mais jovem muitas vezes se desvia completamente da língua como um fenômeno transmitido em casa. Isso é claramente visto nas famílias que, por várias gerações (muitas vezes por mais de 100 anos), mantiveram a língua de seus ancestrais. Os bisavós vieram ao Brasil com seu polonês (geralmente regional), os avós e os pais falavam fluentemente polonês, os jovens adultos de hoje falam-no muito bem, mas seus filhos não falam nada de polonês, o conhecimento da língua dos avós e dos pais se limita ao entendimento das mensagens mais simples. A perda da língua nessas famílias é repentina e radical. A geração dos pais fala bem polonês (a comunicação ocorre sem problemas, eventuais portugalismos/lusitanismos não interferem nela), seus filhos não falam nada polonês. Um dos padres da Colônia Dom Pedro II disse-nos que até as canções polonesas na missa são:

takie najprostsze: Baranku Boży, z mszy późni Serdeczna Matko, Matko Boska Częstochowska, takie proste pieśni. Nawet na ofiarowanie śpiewają pieśń po polsku [tylko] czasami. Nie za dużo, bo młodzi już tego nie rozumieją.

(as mais simples: Cordeiro de Deus, depois Mãe de Coração, Mãe de Deus de Częstochowa, canções simples. Mesmo durante o Ofertório, eles [somente] às vezes cantam em polonês. Não muito porque os jovens já não o entendem.)

Essa situação é causada principalmente pela mudança no estilo de vida das crianças e dos adolescentes. Seus pais, depois de regressar da escola eram "condenados" à companhia dos familiares - falavam polonês com os avós e os pais, ouviam suas histórias, os contatos com os amigos só eram possíveis na escola, depois das aulas eram limitados devido à distância entre as casas (por exemplo, em Santanta, localidade perto de Cruz Machado, as casas ficam na floresta, frequentemente a vários quilomêntros umas das outras). Sobre esse ponto, apresento as três citações abaixo: 
My mówili zawdy, od dzieci w dómu, wszyskie tu na koloniji mówili po polsku, do szkoły my sły, miały my siedym lot iii nic po brazylijsku my nie wiedziały. Naucyli my sie języka brazyliskiego w szkole.

(Conversávamos sempre, desde criança, todos aqui na colônia falavam polonês, até na escola em que íamos, tínhamos sete anos e não sabíamos nada de brasileiro. Aprendemos a língua brasileira na escola.)

Ta, wszyskie po polsku, moja mama przyjechała z Polski, nie umiała po brazylijsku i umarła i ona się nie nauczyła po brazylijsku, my wszyskie po polsku. Po brazlijsku się zawse mówiło, jak do szkoły posed, a tak to po polsku i do dziź dnia jesce mówie po polsku.

(Sim, todos em polonês, minha mãe veio da Polônia, ela não sabia falar brasileiro e morreu e ela não aprendeu brasileiro, todos nós em polonês. Falava-se brasileiro na escola, mas normalmente polonês, e hoje eu ainda falo polonês.)

W domu już dzieci się nie chcą uczyć polskiego. Dawniej, to przed pójściem do szkoły wszyscy mówili po polsku, bo w domu się mówiło po polsku. A teraz telewizja, komputer, to wszyscy zaczynają od portugalskiego. I są duże trudności dla tych dzieci, młodzieży, [żeby w nich polski zachować], przyszli do szkoły i trzeba było po portugalsku. Zresztą polski, niemiecki, włoski to bardzo zostały skrzywdzone te języki za tego, za Vargasa. Zamknął szkoły, zabronił.

(Em casa, as crianças não querem mais aprender polonês. No passado, antes de ir à escola, todo mundo falava polonês, porque o polonês era falado em casa. E agora televisão, computador, todos começam com o português. E há grandes dificuldades para essas crianças, jovens [para manter o polonês vivo nelas], eles vieram à escola e era necessário falar português. De qualquer forma, polonês, alemão e italiano ficaram muito feridos na época de Vargas. Fechou escolas, proibiu.)

Não há necessidade de se aprofundar aqui na questão da(s) doutrina(s) de Vargas; essas temas são bem conhecidos pelos leitores brasileiros. Cito as palavras do padre Malczewski, um homem daqui - do Brasil, autor do texto do livro dedicado ao prof. W. Miodunka:

o período de nacionalização durante o governo do Presidente Getúlio Vargas, que começou em 1938, afetou negativamente o desenvolvimento da educação polonesa e de outros grupos nacionais. Todas as escolas étnicas foram fechadas em virtude das leis de nacionalização. 
[...] Todas as autoridades foram obrigadas a implementar a plena assimilação ao ambiente nacional dos brasileiros de origem estrangeira. $\mathrm{O}$ decreto recomendava aprender português e usá-lo amplamente, além de aprender a história do Brasil e unir estrangeiros a associações patrióticas (essas atividades tinham por objetivo promover a formação de uma consciência brasileira comum). Além disso, o decreto inclui a disposição que determina que as escolas brasileiras devem ser estabelecidas em áreas habitadas por estrangeiros. Somente aqueles que se esforçavam por implementar as recomendações do referido decreto podiam ser professores nessas escolas. [...] O decreto proibia o uso de línguas estrangeiras em locais públicos, quartéis e durante o serviço militar. Também nas igrejas, os sermões deveriam ser pregados na língua oficial, ou seja, o português (MALCZEWSKI, 2016, p. 241).

Uma das minhas interlocutoras mencionou que mesmo "as colônias não podiam ter nomes em língua estrangeira, apenas brasileiros"; portanto, entre outros aspetos, a Colônia Nova Polska mudou seu nome para Dom Pedro II. Hoje, apenas o restaurante dessa povoação lembra o nome anterior.

Afinal, parece que, o que Vargas não conseguiu destruir e arruinar em relação ao conhecimento da língua polonesa, os computadores, a internet e a globalização prejudicaram em um ritmo acelerado. Isso não significa que eu esteja negando o progresso tecnológico, ou que não veja os benefícios da globalização, ou talvez melhor, ao amplo acesso aos recursos da comunicação no mundo de hoje. Todos nós apreciamos o ritmo, a facilidade e o baixo custo da comunicação (até de graça) com os cantos mais distantes do mundo, graças à World Wide Web. Todos nós apreciamos os benefícios educacionais e didáticos resultantes do uso da internet: existem programas de aprendizagem que no interior do Brasil não podem ser superestimados, o que foi observado, por exemplo, pelo embaixador da Polônia no Brasil em 2013-2017, Andrzej Braiter, com quem implementamos o projeto de curso da língua polonesa para iniciantes, na forma de cenas de filmes gravadas pelos estudantes da Escola de Língua e Cultura Polonesa da Universidade da Silésia, disponíveis gratuitamente on-line (http://www.sjikp.us.edu.pl/pl/publikacje/e-nauczanie/polski-dlapoczatkujacych/). Apreciamos a disponibilidade de informações sobre o mundo e essas em qualquer língua. A internet está cheia de programas úteis, inclusive educacionais, para adultos e crianças, que apresentam o conhecimento de uma maneira divertida, ilustrados com lindas fotografias e coloridas imagens, estáticas e animadas. É inegável.

Mas a internet também é - não se pode negar - uma ameaça a certos valores, incluindo a manutenção de identidades étnicas, nacionais, culturais e os vínculos específicos que deles resultam. 
As crianças já não ouvem as histórias dos avós em casa depois de regressarem da escola; elas não acompanham os pais na execução de todas as tarefas domésticas. Ao chegerem em casa após a escola, as crianças sentam-se em frente à tela do computador, laptop ou olham o smartphone. Porque é lá que estão seus colegas e suas fascinações em comum.

Atualmente, a conectividade com a internet mudou totalmente o tipo de contato. As crianças passam a maior parte do tempo livre interagindo com colegas nas redes sociais, jogando, buscando entretenimento na internet - para estarem "na moda" elas precisam se mover no mesmo espaço digital e linguístico que seus colegas. Então, automaticamente, o português se torna a língua da comunicação cotidiana. Embora os cursos da língua polonesa sejam organizados nas escolas, por exemplo, no ano letivo de 2015-2016 apenas seis crianças (incluindo uma menina sem origem polonesa) se matricularam nesse curso (gratuito) na escola de Santana. As aulas em uma escola com mais de 1.000 alunos se realizam por turnos. A participação exige que alguns alunos saiam de casa por volta das seis horas, algo bastante desmotivador. Nas gerações anteriores, essas distâncias, quando não havia ônibus escolares que levavam crianças dos lugares mais distantes, por sua vez, causavam a interrupção total da escolaridade (daí o contato fraco com a língua portuguesa). Portanto, ao considerar os prós e os contras da internet, é necessário pesar bastante o que colocamos em risco. As considerações tecidas aqui são uma tentativa de análise do fenômeno e não a sua valoração. $\mathrm{O}$ acesso ao conhecimento, à educação, ao mundo e às informações sobre ele não é comparado às questões da preservação da língua chamada de "nativa". Portanto, não avalio os resultados dessas relações, somente constato a sua ocorrência.

\section{O MÉTODO, OU SEJA, A IMPORTÂNCIA DAS PESSOAS E SUAS VIDAS}

Todas as descobertas e descrições que utilizo são estudos de caso. W. Miodunka escreveu sobre as possibilidades e os benefícios do uso de estudos de caso, biografias individuais, especialmente biografias e autobiografias linguísticas no artigo Biografia językowa jako jedna z metod badania dwujęzyczności (Biografia linguística como um dos métodos de pesquisa do bilinguismo, MIODUNKA, 2016).

O pesquisador já antes formulou teses importantes para a descrição do bilinguismo, escrevendo, entre outros, que "uma pessoa bilíngue não possui tanto dois sistemas linguísticos separados, senão duas línguas que interagem entre si, a análise da língua deve levar em consideração o cruzamento do limite da norma linguística" (MIODUNKA, 
2014, p. 223). Essa ideia deve ser complementada, acrescentando que se trata também (além de fatos sistêmicos) de ultrapassar a norma do polonês nacional, por assim dizer do polonês polonocêntico. Especialmente, se estamos falando de questões lexicais e, mais especificamente, de empréstimos. Se são pessoas que vivem em lugares remotos sem contato com o polonês atual, o léxico que aparece atualmente no polonês na Polônia é substituído por elementos emprestados da língua que envolve a língua polonesa da diáspora, neste caso o português.

As pesquisas baseadas em estudos de caso são valiosas em si mesmas e, como base para generalizações posteriores, as biografias individuais são importantes, porque "o pesquisador deve se esforçar para conhecer as condições internas e externas do funcionamento da pessoa pesquisada em um determinado grupo social" (MIODUNKA 2016, p. 51) - e isso é possível apenas como resultado de entrevistas muito aprofundadas, vendo-se a situação, referindo-se em conversas a fatos lançados casualmente que chamam a atenção do pesquisador e que não foram analisados espontaneamente pelo falante, que geralmente é menos consciente do impacto de certos fatos em sua "configuração linguística" e apenas por meio de perguntas adicionais do pesquisador eles permitem extrair certos fatos, fenômenos e processos dos recessos da memória. Geralmente, podem-se generalizar as conclusões até certo ponto, porque, embora essas biografias frequentemente difiram em detalhes e fatos específicos, elas ilustram certas tendências que se repetem. No entanto, deve-se lembrar sempre das limitações desse método, conforme enfatizado por Miodunka (2016, p. 52), citando a máxima de Pilch e Bauman (2001, p. 300): “O conhecimento obtido durante o estudo de caso apenas permite afirmar que ‘assim acontece' e não que ‘é assim”".

Conforme o próprio autor comenta, durante a pesquisa e redação da monografia sobre o bilinguismo polonês-português, "a hipótese originalmente concebida era a maior vitalidade da língua polonesa nas colônias dominadas pela população polonesa no interior do Brasil, em comparação com a menor vitalidade da nossa língua [polonesa] nas grandes cidades brasileiras" (MIODUNKA, 2016, p. 64). Essa tendência, como mencionei anteriormente, hoje parece estar parcialmente se invertendo ou se nivelando. A língua desaparece também no interior. Às vezes ou até cada vez mais, a polonidade está se tornando um ornamento, um acréscimo folclórico à vida cotidiana, mesmo em um lugar onde praticamente todos são de origem polonesa, tendo apenas ancestrais poloneses. Porque, embora não seja mais a regra de formar casamentos endoétnicos e não exista, a princípio, tal obrigação ou pressão do entorno, é a tradição que influencia as escolhas por cônjuges do mesmo grupo étnico. 
$\mathrm{Na}$ geração mais jovem, o conhecimento de línguas étnicas ou minoritárias, ou (como é chamado na Austrália) 'comunitárias' (ver DĘBSKI, 2016, p. 90), desaparece essencialmente (não apenas no Brasil). Nas grandes cidades há mais tentação de falar apenas a língua local, mas há uma oportunidade maior de aprender polonês em cursos, participar de eventos culturais poloneses, palestras e conferências abertas (na Universidade, nas sociedades polonesas, na Cada da Cultura Polônia-Brasil), etc. No interior, por sua vez, antigamente a casa da família dominava o ensino de línguas e agora esse papel foi assumido pela internet:

Dawniej to przed pójściem do szkoły wszyscy mówili po polsku, bo w domu się mówiło po polsku. A teraz telewizja, komputer.

(Antigamente, todo mundo falava polonês antes de ir à escola, porque o polonês era falado em casa. E agora a televisão, o computador.)

Atualmente, a criança depois da escola contata seus colegas pela internet, usando o português, de modo que o polonês doméstico dessa criança se afasta completamente, sendo limitado a algumas palavras básicas. Esse processo já não pode ser esquecido na pesquisa, porque "o fenômeno de bilinguismo consiste em adquirir duas línguas, mas também esquecer uma delas, a menos usada; o uso estável de duas línguas ao longo do tempo, mas também uma falta temporária de contato com uma das línguas, enfraquecendo seu conhecimento" (MIODUNKA, 2016, p. 80-81).

\section{TENDÊNCIAS E PROCESSOS OPOSTOS}

As proibições impostas por Vargas causaram muitos danos de identidade a imigrantes de diferentes nacionalidades no Brasil. Os poloneses, no entanto, mantiveram sua língua num nível que é digno de admiração. As distâncias em um país com uma área próxima à superfície da Europa provavelmente causaram que as leis de Vargas tivessem um impacto menor no interior, o que permitu a vários grupos nacionais/étnicos proteger grande parte da sua herança cultural. Além disso, comparando a situação linguística dos poloneses no Brasil, mesmo com o período de partições na Polônia, podemos defender a tese sobre a teimosia polonesa e a resistência às ações contra a língua polonesa, que muitas vezes causam reações opostas às pretendidas pelas autoridades lingüísticas opressoras. Cito: 


\begin{abstract}
A moja mama to jeszcze chodziła do szkoły, a ja uczyłam się, to znaczy mówiliśmy po polsku w domu, ale trzeba było zamykać okna i zaciemniać okna na przykład.
\end{abstract}

(Minha mãe ainda ia à escola e eu estudava, ou seja, falava-se polonês em casa, mas era preciso fechar as janelas ou escurecer as janelas, por exemplo).

As tendências de se assimilar às condições linguísticas e culturais do país de assentamento não podem ser subestimadas. Ganhar prestígio, elevar o status (objetivo e subjetivo) no novo ambiente é frequentemente identificado pelos imigrantes com a necessidade de assimilação o mais rápido possível, porque a posição humana depende, entre outros, do prestígio da língua que usa e o português pertence ao grupo das oito maiores línguas do mundo (as com mais de 150 milhões de falantes). Existem casos conhecidos em vários países de se livrar deliberadamente da língua nativa da comunicação em casa; alguns até por essa assimilação e irreconhecibilidade étnica mudaram oficialmente seus sobrenomes. Alíngua polonesa no Brasil sobreviveu a todas essas proibições e dificuldades. No entanto, é lamentável dizer que aquilo que as autoridades não conseguiram fazer durante cem anos é feito pela cultura pop e pela globalização voluntária.

\title{
AUTOCONSCIÊNCIA LINGUÍSTICA
}

Ao refletir sobre o bilinguismo dos imigrantes, são importantes suas autoconsciência e autoavaliação de seus conhecimentos de ambas as línguas. Os poloneses com que conversei no Brasil reparam nas diferenças entre seu polonês e o padrão; conhecem esse fato, embora não saibam identificar as diferenças.

Entre os poloneses no Brasil (gerações mais antiga e intermediária), há consciência da qualidade de sua língua, a convicção de que ela é diferente daquela hoje falada na Polônia. Por exemplo, um padre da colônia Dom Pedro II (que trabalha no Brasil há várias décadas) menciona:

Ale to nawet nie ma sensu mówić kazania czy homilii po polsku, bo połowa nie zrozumie, nawet starsi. Języka współczesnego nie rozumieją. To się zamknęło, z tym językiem, co oni przijechali, tym operują cały czas.

(Não faz sentido dizer um sermão ou homilia em polonês, porque metade não entende, nem os mais velhos. Eles não entendem a língua moderna. Isso foi fechado, com a língua com que eles vieram, eles operam o tempo todo.) 
A língua trazida da Polônia - de várias regiões da Galícia, da Silésia da região de Opole e de outras regiões - era falada por imigrantes da primeira geração e por aqueles que nasceram no Brasil e a aprenderam em casa, dos avós, pais e vizinhos mais próximos (citação: "My mamy jynzyk taki bardzi starodowny. Starodawny język jes, jaki przywiezły z Polski" ("Temos uma língua tão antiquada. A língua antiquada que eles trouxeram da Polônia").

Foi a língua trazida da Polônia que ocupou um lugar de destaque nas malas e nos pacotes dos migrantes. A língua ocupou o lugar principal na sua bagagem. Eles a pegaram inteira porque não pesava nada. A língua polonesa, a língua é para os poloneses um dos componentes mais importantes da polonidade. Sempre foi assim. Estamos cientes de sua importância para nossa identidade, que é mencionada até no preâmbulo da Lei da Língua Polonesa, adotada em 7 de outubro de 1999:

O Parlamento da República da Polônia:

- considerando que o polonês é um elemento básico da identidade nacional e um bem da cultura nacional,

- considerando a experiência da história, quando a luta dos invasores e ocupantes contra a língua polonesa era uma ferramenta de desnacionalização,

- reconhecendo a necessidade de proteger a identidade nacional no processo de globalização,

- reconhecendo que a cultura polonesa é uma contribuição para a construção de uma Europa comum e culturalmente diversificada e que a preservação dessa cultura e seu desenvolvimento só é possível mediante a proteção da língua polonesa,

- reconhecendo essa proteção como o dever de todos os órgãos e instituições públicas da República da Polônia e como o dever de seus cidadãos promulga esta lei. (POLÔNIA, 1999, p. 1)

O reconhecimento do papel da língua na construção de identidades étnicas e nacionais é declarado nos parágrafos sobre o respeito aos direitos - incluindo direitos linguísticos - da Lei sobre minorias nacionais e étnicas e sobre a língua regional ${ }^{6}$ polonesa de 6 de janeiro de 2005 (POLÔNIA, 2005, p. 1). Nas disposições sobre as características constitutivas das minorias nacionais e étnicas, encontramos as disposições que, na acepção da Lei, definem uma minoria nacional como um grupo de cidadãos que atendem conjuntamente às seguintes condições:

\footnotetext{
${ }^{6}$ Ustawa o mniejszościach narodowych $i$ etnicznych oraz o języku regionalnym z 6 stycznia 2005 roku
} 
1) é menor que a parte restante da população da República da Polônia;

2) distingue-se significativamente de outros cidadãos na língua, cultura ou tradição;

3) esforça-se para preservar sua língua, cultura ou tradição;

4) conhece sua própria comunidade histórica nacional e concentra-se em sua expressão e proteção;

5) seus antepassados viviam no atual território da República da Polônia por pelo menos 100 anos;

6) identifica-se com a nação organizada em seu próprio estado.

A lei chama principalmente a atenção para os valores específicos da nação cultural, ou seja, valores culturais, definindo-os geralmente com as palavras: cultura, cultural ou tradição. Ao valor cultural "língua" é atribuído um lugar especial, único e prioritário, uma vez que em documentos tão importantes (não apenas em polonês, porque a Lei se baseia nas disposições da Carta Europeia das Línguas Regionais ou Minoritárias adotada em 1992 pelo Conselho da Europa), é explicitamente mencionada duas vezes.

Os brasileiros de origem polonesa estão cientes da "antiguidade" de sua língua trazida da Polônia pelos ancestrais. Talvez haja menos senso de distinção regional de algumas palavras e frases. Eles podem falar sobre velhos hábitos e explicar as palavras que usam nesta ocasião. Há palavras em sua língua que até muitos jovens poloneses na Polônia não entendem hoje em dia, os quais se afastam de tradições e costumes, da economia familiar rural, de famílias multigeracionais e, finalmente, das manifestações folclóricas e do folclore.

Assim, nas histórias dos poloneses brasileiros aparecem:

- cepowiny - regionais, mais conhecidas como oczepiny (um ritual durante a festa de casamento, no qual a noiva torna-se uma mulher casada);

- rękowiny, zrękowiny - hoje no polonês geral substituídas por zaręczyny (noivado);

- chodzić na katechizm - hoje, ir às aulas de religião; nesse sentido a palavra catecismo (katechizm) já não aparece, sendo que atualmente é usada ao se referir ao livro que contém as principais regras da religião católica, na forma de perguntas e respostas.

Mas - é claro - os pesquisadores dão igual ou até maior atenção às aquisições na língua polonesa da comunidade polonesa no Brasil - os portugalismos ou, talvez, brasileirismos? Os empréstimos na língua dos grupos de migrantes costumam ser classificados negativamente. Acredita-se que eles poluem a língua polonesa, que levam à criação de uma interlíngua, uma mistura de línguas e que geralmente são o resultado 
da alternância de códigos e da preguiça linguística. No entanto, se olharmos para os brasileirismos observados nessa comunidade, notamos que, em maioria, são nomes de elementos da realidade que não existiam na época da partida de seus ancestrais da Polônia (especialmente quando se trata de emigração a partir do final do século XIX) ou que não haviam chegado à Polônia, não eram conhecidos na Polônia. Então... os ancestrais de meus interlocutores atuais, do século XXI, não puderam trazê-los na bagagem da Polônia. Tem-se, por exemplo, seguintes empréstimos da língua portuguesa:

- awion - "oni polecieli do Polski awionem" (“eles voaram para a Polônia de awion"); no espaço público, apareceu na consciência mais ampla apenas em meados do século XX. Os primeiros testes de avião não eram, para os migrantes que estavam construindo suas novas fazendas, uma questão de primeira importância;

- bicykleta - bicicleta, sua história remonta ao século XIX, mas a produção na Polônia na década de 1930 atingiu apenas 5000 peças, e elas certamente não chegaram às aldeias e cidades das quais os poloneses partiram para atravessar o oceano;

- laranże - laranjas, certamente não estavam em casas polonesas na virada do século;

- pysyski - pêssegos, aqui a situação era semelhante;

- laraski - provavelmente trata-se da fruta conhecida como kin-kan, fruta pequena com casca alaranjada;

- milija - milho, ouso supor que não fosse comum no campo polonês;

- fizión - talvez tenha substituído a palavra polonesa fasola por ser diferente? Normalmente o feijão polonês é branco e grande, não o feijão preto pequeno.

Isso é confirmado por outras interferências do português do Brasil, as palavras que não são usadas nas conversas cotidianas, na comunicação cotidiana comum, principalmente na comunicação polonesa, que, no entanto, continua sendo comunicação doméstica:

- "to z pocontku było tak, bardzo... jak to separado" ("no começo foi tudo separado");

- “majóm miejsce rezerwado w uniwersite" ("eles têm um lugar reservado na universidade);

- "rzónd rozdawoł ale miały kontrato" ("governo dava, mas tinha contrato")

- "miały inkse komportamenty, zachowanie i dziś jak to... komprehensja współżycie" ("Tinha outro comportamento e hoje, compreensão, convivência...”) 


\title{
AVALIAÇÃO DAS LÍNGUAS DE MIGRANTES
}

A metodologia de ensino de línguas estrangeiras praticamente não se beneficiou dos achados do cognitivismo. Provavelmente, isso se deve ao fato de os resultados obtidos na aquisição da imagem linguística do mundo serem imprecisos e, portanto, pouco mensuráveis. No entanto, como escreve Taylor,

\begin{abstract}
o próprio fato da existência de expressões que desafiam o princípio da composicionalidade não precisa negá-lo de forma alguma - desde que essas exceções possam ser facilmente identificadas como tais. $\mathrm{Na}$ realidade, porém, verifica-se que as exceções ao princípio da composicionalidade não formam uma categoria estritamente definida, porque muitos elementos da língua são, em certa medida, idiomáticos, muitos deles são, em certa medida, expressões metafóricas e a maioria está sujeita à interpretação pragmática. Na análise final, verifica-se que a composicionalidade total é uma exceção (TAYLOR, 2007, p. 119).
\end{abstract}

Se os princípios do cognitivismo fossem totalmente aceitos em vários estudos linguísticos, a necessidade de avaliação e aceitação na avaliação da porcentagem de roteiros culturais deveria ser assumida. Em outras palavras, seria necessário encontrar uma ferramenta para mensurar a porcentagem dos comportamentos novos/adquiridos em em relação aos já encontrados no existência social de um indivíduo. Dependeria da intuição e das habilidades de interpretação do pesquisador esse reconhecimento de quão próximo o pesquisado está ou se afasta da cultura examinada no estudo. Existem muitas etapas intermediárias na língua das comunidades migrantes, que são o terceiro - nem o próprio nem o novo - valor da imagem linguística do mundo. Os pontos focais dessas etapas foram indicados por Miodunka, mostrando ao mesmo tempo que a realização das identidades migrantes nas gerações subsequentes, e mesmo na vida de uma determinada pessoa, é uma espécie de continuum.

Os poloneses brasileiros, sabendo que sua língua difere, pouco ou muito, frequentemente significativamente, da língua polonesa atual, sentem um orgulho evidente pelo fato de ela ter sido preservada. Cientes de interferências e empréstimos, estão claramente satisfeitos com os elogios dos poloneses ao esforço em preservar a língua polonesa e transmiti-la de geração em geração:

Ale jesce sóm ludzie takie tu, co dobrze po polsku rozmawiajóm. A my tu tak sie naucyli, ale tak troske, tak zmiysane po polsku i po brazylijsku. 
(Mas ainda há gente como esta aqui, que fala bem polonês. E nós aprendemos assim, mas um pouco misturando o polonês com o brasileiro.)

Jak my byli w Polsce za trzy lata w tył, to „rozmawias tak jak mój dziadek, mój łojciec". Bo tam tyz język się przeinacył.

(Quando estávamos na Polônia há três anos, diziam "você fala como meu avô, meu pai”. Porque aí que a língua também mudou.)

My w tamtym roku byli w Polsce, to my tam do sklepu kupić takie rozmaite rzecy i my mówi, że my sóm z Brazilie, to ta, co sprzedawała tam, mówi: „Matko Boska, jak ładnie umicie rozmawiać”, ona myślała, że „same sóm Braziliany”, jo mówie tak, ze w Brazilie jest wiyncy Polaków jak tu w Polsce.

(Nós estivemos na Polônia naquele ano, vamos lá para comprar uma variedade de coisas na loja e dizemos que somos do Brasil, e quem vendeu lá, diz: "Mãe de Deus, como vocês falam bonito", ela pensou que "éramos brasileiros", eu digo, que há mais poloneses no Brasil do que aqui na Polônia.)

As línguas étnicas dos imigrantes no Brasil estão passando por um renascimento. Eventos, fatos e instituições percebidos nas categorias de alta cultura têm um papel enorme em aumentar o prestígio da língua e da identidade polonesas: é o trabalho de Paulo Leminski, um poeta de ascendência polonesa conhecido em todo o Brasil, que intitulou um de seus poemas Powróciło moje polskie serce ( $O$ meu coração de polaco voltou), são duas áreas universitárias de língua e cultura polonesa: na Universidade Federal do Paraná em Curitiba e na Universidade de Brasília, ou a criação de cursos de polonês na UNICENTRO, em Irati. Afinal, "o trabalho de base" é muito importante: escolas de língua polonesa organizadas no Brasil, oficinas de metodologia para professores locais (organizadas há muitos anos pelo Consulado-Geral da República da Polônia em Curitiba), com participação de especialistas em ensino de língua da Polônia, palestras, seminários e, finalmente, bolsas de estudo concedidas a pessoas de origem polonesa no Brasil para realizar estudos completos ou parciais na Polônia e para as escolas de verão. São esses bolsistas e participantes de oficinas glotodidáticas que garantem o renascimento do polonês na geração mais jovem - eles serão professores conscientes do prestígio e do potencial internacional da língua polonesa. Acredito que o aprendizado escolar da língua polonesa no futuro será a maneira básica de adquiri-la, mesmo para as pessoas de famílias monoétnicas. 


\section{CONCLUSÃO}

Hoje em dia, vale a pena mostrar para os mais jovens o conteúdo dos baús de viagem trazidas pelos bisavós. Vale a pena conscientizá-los da beleza e do enorme valor dessa bagagem. Vale a pena apresentar conclusões de cientistas de todo o mundo. Por exemplo Ellen Bialystok (2001), professora de psicologia na Universidade de Toronto, prova que as pessoas bilíngues não só não sofrem de uma "confusão na cabeça", mas são melhores em executar várias tarefas ao mesmo tempo. Sabe-se também que as pessoas bilingues segregam informações com mais facilidade, dividem a atenção e conseguem enxergar o problema de diferentes ângulos (são mais criativas). E esses fatos não são surpreendentes à luz das funções desempenhadas por ambos os hemisférios, cuja cooperação e complementação mútua é necessária para um funcionamento humano mais eficaz. O bilinguismo também traz benefícios práticos: pode-se estudar na Polônia, que os aproxima de empregos em grupos internacionais da Europa, onde o conhecimento do polonês - uma das principais línguas da União Europeia - pode ser uma habilidade desejável.

Para a comunidade polonesa, a língua polonesa é a língua pela qual os vínculos são estabelecidos: nas gerações mais antigas, ela pode expressar o que toca na alma; para os jovens, pode-se tornar uma língua de contato com o mundo e com a grande comunidade polonesa no Brasil e em outros países. Talvez não seja tão comum como o inglês, mas é a língua de seus corações e de suas almas, a língua para expressar emoções e sentimentos, mas também a língua de ciência, a língua de muitos ganhadores do Prêmio Nobel. É a língua que está no coração polonês, o qual volta, como diz o título do poema de Paulo Leminski. 


\section{REFERÊNCIAS:}

ALTERMATT, U. Sarajewo przestrzega. Etnonacjonalizm w Europie. Introdução de Tadeusz Mazowiecki. Tradução de Grzegorz Sowinski. Kraków: Znak, 1998.

BIALYSTOK, E. Bilingualism in Development: Language, Literacy, and Cognition. Cambridge: Cambridge University Press, 2001. Disponível em: $<$ https://www.cambridge.org/core/books/bilingualism-in-development/F4B33562B852B 2DAF6A4F7BBE7E7DD2E >. Acesso em 20 ago. 2020.

DĘBSKI, R. Badania wielojęzyczności w Australii. Implikacje dla badań dwujęzyczności polsko-obcej. In: DĘBSKI R.; MIODUNKA, W.T. (Ed). Bilingwizm polsko-obcy dziś. Od teorii i metodologii badań do studiów przypadków. Kraków: Uniwersytet Jagielloński, 2016. p. 89-106.

CHLEBOWCZYK, J. Świadomość historyczna jako czynnik narodotwórczy. Zarys problematyki teoretycznej. Dzieje Najnowsze, r. 9, n 1, p. 103-119, 1977.

CHLEBOWCZYK, J. O prawie bytu matych i młodych narodów. Katowice: Śląski Instytut Naukowy, 1983.

KŁOSKOWSKA, A. Kultury narodowe u korzeni. Warszawa: PWN, 1996.

MALCZEWSKI, Z. Nauczanie języka polskiego w Brazylii - od szkół polskich osadników do polonistyki na brazylijskich uczelniach federalnych. In: MIODUNKA; W. SERETNY, A. (Ed.). Język, literatura i kultura polska w świecie. Kraków: Uniwersytet Jagielloński, 2016. p. 239-246.

MIODUNKA, W. Teoria pól językowych: społeczne i indywidualne ich uwarunkowania. Warszawa: PWN, 1980.

MIODUNKA, W. Dwujęzyczność polsko-obca w Polsce i poza jej granicami - Rozwój i perspektywy badań. LingVaria, v. 17, p. 199-226, 2014.

MIODUNKA, W. Bilingwizm polsko-portugalski w Brazylii: w stronę lingwistyki humanistycznej. Kraków: Universitas, 2003.

MIODUNKA, W. Biografia językowa jako jedna z metod badania dwujęzyczności. In: R. DębSki, W.T. Miodunka (Ed.). Bilingwizm polsko-obcy dziś: od teorii i metodologii badań do studiów przypadków. Kraków: Uniwersytet Jagielloński, 2016. 
POLÔNIA. Parlament Rzeczypospolitej Polskiej. Ustawa z dnia 7 października 1999r. o języku polskim. ISAP - Internetowy System Aktów Prawnych, Varsóvia, 8 nov. 1999. Disponível em: <http:/isap.sejm.gov.pl/isap.nsf/download.xsp/WDU19990900999/U/ D19990999Lj.pdf>. Acesso em 20 ago. 2020.

POLÔNIA. Parlament Rzeczypospolitej Polskiej. Ustawa o mniejszościach narodowych i etnicznych oraz o języku regionalnym z 6 stycznia 2005 roku. ISAP - Internetowy System Aktów Prawnych, Varsóvia, 31 jan. 2005. Disponível em: $<$ https://isap.sejm.gov.pl/isap. nsf/download.xsp/WDU20050170141/U/D20050141Lj.pdf>. Acesso em 20 ago. 2020.

TAMBOR, J. Mowa Górnoślazaków oraz ich świadomość językowa i etniczna. Katowice: Wydawnictwo Uniwersytetu Śląskiego, 2006.

TAMBOR, J.; CUDAK, R.; ACHTELIK, A. Academic education of foreigners (based on the example of Polish studies). Universidade em Debate, n. 2, 9, 2014

TAMBOR, J. Po polsku, po brazylijsku i po portugalsku - o świadomości językowej Polonii brazylijskiej; odrodzenie i zanikanie języka. Postscriptum Polonistyczne, n. 1 (21), p. 221-236, 2018.

TAYLOR, J.R. Gramatyka kognitywna. Trad. Pol. M. Buchta e Ł. Wiraszka. Kraków: Universitas, 2007. 